\title{
NEW MOTHS OF THE GENUS TRICHOSTIBAS.
}

\author{
By August Busck, \\ of the U. S. Department of Agriculture.
}

The moths of the genus Trichostibas are rather common in Central and South America and are frequently taken by collectors, because they are attracted by light.

In the U. S. National Museum are good series of a dozen species of this genus, including all but one of the species described from continental America and the four new species, described in this paper. ${ }^{a}$ In addition to these, two species are described from Cuba and one from Porto Rico by Zeller; and one species is described from Jamaica ${ }^{b}$ by Lord Walsingham as Trichostibas pallidicostella; but if the venation of the hind wing is correctly given, this is clearly not a Trichostibas, as was suggested in his description.

The only species found in United States has been for several years identified as Trichostibas calligera Zeller, ${ }^{c}$ from Cuba; but a careful reading of Zeller's description proves this to be a groundless identification, and the Florida species must be known under its American name, Trichostibas parvula Edwards, ${ }^{d}$ which has hitherto wrongfully been placed as a synonym of $T$. calligera Zeller.

While the adults of this genus are thus tolerably well known, none of the larvæ have ever been described, and only a few of the species have been associated with and reared from their remarkable cocoons.

The moths of the genus are rather obscure, dull-colored insects, though with a charm of their own in their soft brown or bluish colors. Their cocoons, on the contrary, are very striking objects, rarely met with, and it is the opportunity to describe one of these and to present an adequate illustration of it, that is the main reason for the present paper.

$a$ There are besides these cotypes and large series of three other species of this genus, which have been described by Lord Walsingham, and which will appear in the near future in his volume of the Biologia Central-Americani.

$b$ Proc. Zool. Soc. London, 1897, p. 115.

$c$ Horæ Soc. Ent. Rossicæ, vol. 13, 1877, p. 231.

$d$ Papilio, vol. 1, 1881, p. 80 . 
TRICHOSTIBAS ISTHMIELLA, new species,

Labial palpi black. Tongue white. Face and head deep blackish blue. Antennæ dark blue. Thorax lighter, slaty blue. Forewings dark violet, clouded with lighter, inky, bluish violet. The color appears very nearly uniform under a lens, but in certain lights two broad,ill-defined bands of the lighter color can be made out, one at basal third, one at apical third, and the extreme tip is also somewhat lighter. Cilia dull blackish blue. Hindwings very dark, dull blackish fuscous, darker than those of any of the other described species and but very slightly transparent, just enough to distinguish the still darker veins. Abdomen deep metallic blue; ovipositor long, horny. Legs deep blue. Alar expanse, $37 \mathrm{~mm}$.

Habitat.-Gorgona, Canal Zone, Panama. E. A. M. Swaine, coll. Type.-Cat. No. 13151, U.S.N.M.

A cocoon of this species with a live pupa was received through the mails on April 16, and on the same day the moth, a female, issued.

The cocoon is of the general open network type of the genus and is apparently very similar to that of $T$. fumosa Zeller, described by Lord Walsingham. ${ }^{a}$ A picture of similar cocoons is given without identification of the species by Henry Edwards in The Standard Natural History, vol. 2, 1884, p. 438.

In the present species the cocoon is suspended from a leaf by a stiff, silken thread more than 13 inches long, which, like the cocoon itself, is of a bright salmon red color. This supporting thread divides into three branches at the top of the cocoon, two of which form the edge of the opening through which the moth issues, while the third is continued along the one side of the cocoon, but does not protrude beyond it as in the cocoon of our Florida species. These thick threads are evidently spun first by the larva, which, suspended on them in midair, makes the regular open network between them and around itself. The cocoon is kidney-shaped, 19 by $10 \mathrm{~mm}$., and consists of heavier parallel threads about $1 \frac{1}{2} \mathrm{~mm}$. apart, connected by thinner cross threads about $1 \mathrm{~mm}$. apart and underlaid by an irregular open network of very fine threads. The moth issues through the hole at the upper end; at the lower end the cocoon terminates in a short, open neck, through which the larval skin is pushed out after pupation, thus insuring a clean, airy habitation, free from anything that might become water-soaked, or by its smell attract ants, the ever present enemy of other insect life in the Tropies. The entire elaborate contrivance is presumably a very effective protection against ants during the defenseless pupa period, for even should an ant attempt to climb down the long suspending thread it would 
probably be-shaken off by the lusty violent jerks of the pupa, which were observed in the present specimen, whenever it was disturbed.

I am under obligation to Mr. T. W. Smillie of the U. S. National Museum for the life-sized photograph, which enables me to show the figure of the moth and its cocoon (Plate 35).

The species is by far the largest described in the genus and very distinct from the unicolored species, to which it comes nearest, by its size, its ornamentation, and its very dark hindwings.

TRICHOSTIBAS CHIQUITA, new species.

Labial palpi bluish black. Face and head bluish or greenish black. Antennæ deep blue. Thorax greenish black. Forewings unicolored, shiny, metallic bluish or violet black; costa nearly straight, slightly convex on its outer third; apex pointed; termen oblique. Hindwings transparent, sparsely covered with dull black scales; veins black; in the males with a strong, brown hairpencil at base of costa. Abdomen bluish black; ovipositor hardly protruding; male genitalia strongly developed, with long, thin black-scaled claspers and with two expansible tufts of yellow bristles.

Alar expanse, 20-23 mm.

Habitat.-Juan Vinas, Tuis, and Florida, Costa Rica. William Schaus, coll.

Type.-Cat. No. 13152, U.S.N.M. Cotypes in British Museum.

This is the smallest of the described continental species and comes nearest to the West Indian species, described by Zeller, from which it differs by the darker forewings and by the dark brown costal hairpencil in the males.

\section{TRICHOSTIBAS COSTARICE, new species.}

Labial palpi blackish brown. Face blackish brown. Antennæ dark metallic blue. Head light brown. Thorax light brown, with whitish apex and posterior tip. Forewings deep maroon brown, with a strong purplish sheen and with dirty, brownish white markings. These markings are poorly defined and are gradually shaded into the dark color; the costal half from base to near apex is unmottled dark brown; on the dorsal part of the wing the white predominates and contain a large oval brown spot on vein $1^{\mathrm{b}}$ at basal third, which, by a narrow oblique brown streak, is connected with the upper dark part near the middle of the wing. From the costal dark part projects a spur downwards at apical fourth, which terminates in a nearly separated round brown spot; terminal and extreme apical part white; cilia light brown. Hindwings blackish fuscous, semitransparent except at apex; in the males with a strong, light ochreous, costal tuft. Veins 2 and 3 stalked in the males, separate in the females. This is merely an extreme case of the normal condi-

Proc.N.M.vol.38-10-34 
tion in all the species of the genus, where veins 2 and 3 are always closer together in the males than in the females. Abdomen and legs blackish brown. Ovipositor protruding, horny, reddish. Male claspers likewise red and horny.

Alar expanse, 30-32 mm.

Habitat.-_Juan Vinas, Sixola River, and Tuis, Costa Rica. William Schaus, coll.

Type-Cat. No. 13154, U.S.N.M. Cotype in British Museum.

Though not unicolored, this species, nevertheless, belongs nearest to the unicolored group of the genus and forms an intermediate link between this and the spotted group. The species is nearest in size and in ground-color to hephrstiella Zeller, from which it is at once separated by the ornamentation.

TRICHOSTIBAS VENATELLA, new species.

Labial palpi, face, head, and antennæ bluish black. Thorax bluish or greenish black, with two large oval white spots; patagina bluish black. Forewings blackish brown, with strong metallic blue and green sheen and with dirty white markings, as follows: across the wing near the base is a row of three irregular round white spots, an upper near to but not touching the costal edge, a lower near to but not touching the dorsal edge, and a somewhat larger central spot. Just beyond the middle of the wing is a broad band of white, broken up by the black veins into seven irregular oblong spots; one between the costal edge and vein 11; one between vein 11 and vein 10 ; one on the small cell cut off by the internal vein; one, the largest, on the main cell; one between this and vein 2 ; one between vein 2 and the fold, and one elongate pointed white spot between the latter and the dorsal edge. All the intervals between the apical and terminal veins dirty white; the veins themselves black. Entire edge of the wing narrowly black. Cilia blackish brown. Hindwing dark fuscous, but rather transparent on the basal half, more or less opaque on the outer half. Abdomen bluish black. Ovipositor horny, protruding, reddish.

Alar expanse, 30-31 mm.

Habitat.-Castro, Parana, Brazil. William Schaus, coll.

Type.-Cat. No. 13153, U.S.N.M.

This is one of the easily distinguished spotted group of species in the genus and the largest described species of that group. It is nearest to and greatly resembles T. iophlebia Zeller, but is larger, darker, bluish black instead of violet, and has the white portion of the wing much more restricted than Zeller's species. In this latter particular, as well as in general habitus, it is much like T. imitans Felder, but is a larger and darker form than that species. 


\section{$2 \mathrm{BHL}$ Biodiversity Heritage Library}

Busck, August. 1910. "New moths of the genus Trichostibas." Proceedings of the United States National Museum 38(1765), 527-530.

https://doi.org/10.5479/si.00963801.38-1765.527.

View This Item Online: $\underline{\text { https://www.biodiversitylibrary.org/item/32576 }}$

DOI: https://doi.org/10.5479/si.00963801.38-1765.527

Permalink: https://www.biodiversitylibrary.org/partpdf/36105

\section{Holding Institution}

Smithsonian Libraries

\section{Sponsored by}

Smithsonian

\section{Copyright \& Reuse}

Copyright Status: NOT_IN_COPYRIGHT

This document was created from content at the Biodiversity Heritage Library, the world's largest open access digital library for biodiversity literature and archives. Visit BHL at https://www.biodiversitylibrary.org. 